\title{
【誌上討論室 】
}

会員諸兄姉に広く関心があたれているテーマについて，此較的気軽に誌上で議論できたら，というこ 提案があり，誌上での討論記事を取り上げることに致しました。最初のテーマは「ごみ有料化」です。 以下に揭載します記事は, 北海道大学の松藤敏彦, 田中信害両氏の意見であり,この討論のスタート点 と致します。会員諸氏の見解をお奇せ下さい。なお，この討論室の最低限のルールは (1)感情的・感覚 的な見解はご遠慮頂くこと, (2)簡潔さを求めるために図表ともで刷り上がり 1 ～ 2 頁 (38字 $\times 40$ 行原 稿用紙 3 枚）以内のあの，と致したいと思います。活発で建設的な討論となることを期待致します。

- 編集幹事会

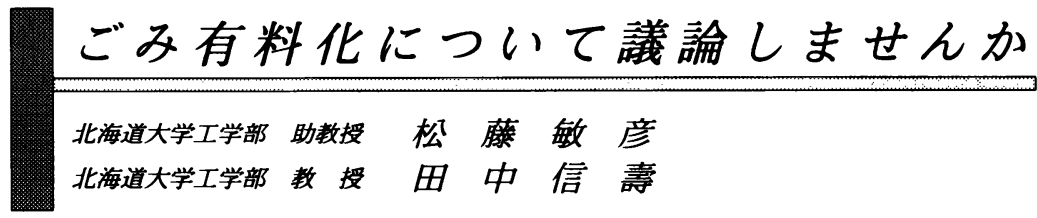

昨年 6 月以降，全国市長会，環境庁，厚生省が相次いでごみの排出量抑制の有勃な手段として有料制導入を提言し， 最近では多くの自治体が有料化を実施あるいは導入を検討している。しかし, 有料化の議論にはまだ不十分な点があ るように思うので，誌上を借りて意見を述べ，新たな議論をよびかけたい。

有料化の実施状況については, 厚生省, 全国市長会による調查結果が引用されることが多いが, 全国 662 市を対象 とした調查報告書（ごみ処理費用有料化実態アンケート調查結果報告，日報，1993 年 2 月）が筆者の手元にある。 これには自治体の回答がそのまま収録されているため, あらためて整理し直してみた。ただし,ごみ減量効果の点で 不然ごみのみの場合, あるいは資源ごみ, 一時多量ごみの有料化については除外すべきと考え, 可然ごみについての み集計した。

処理料金ユーザー徵収はごみ袋に課金するのが最も一般的であるため「有料ごみ袋=ごみ処理有料化」のように考 えられている。ところが，「ごみ袋を有料の指定袋にしているか」との設問に対して yes と回答した 94 市（一定枚 数無料の市は除く）のうち,「処理費用としてその一部を住民から徵収している」と答えたのは約 4 分の 1 の 25 市に すぎない。図 1 に袋の価格を示すが，「費用徵収していない」としている市（ $\triangle$ 印）の平均は 14.8 円であり（袋価格 の記載がある 53 市の平均で，袋の大きさにより価格を変えている場合は最も高い価格を用いた），これは従来からの 市販の袋価格と変わりがなく，単に袋料金として徵収しているとの自治体の考えのあらわれである。アンケートでも， いくつかの市では「袋自体の価格で有料化ではない」との注釈を加えている。一方，「費用徵収している」と答えた 市（○印）には「有料化のために価格を上乗せ」したとの意識が見られるところああるが，「徵収していない」とし た市と同程度の価格であるところが多い。袋価格の徵収ならば，住民にとっては単に袋が指定されただけで金銭的な 負担に変化はない。厚生省調查の「全市町村の $35 \%$ で有料化実施（多量ごみを除く重量制は 19.7\%)」との数値は, 図 1 のどの部分にあたるのだろうか。ごみ有料化とは何をさすのだろうか。

さらに，有料化の方法を検討してみよう。有料化によるごみ減量の例としては，(1)北海道伊達市「市指定袋を 60 円で販売し，それ以外のものは回収しない」，(2)滋賀県守山市「可燃ごみ用の袋を 110 枚までは大 20 円, 小 17 円で 販売し，111 枚目からは 150 円に引き上げる」，(3)島根県出雲市「40リットルの袋を年間 100 枚各家庭に無料で配布 し, それ以降の分は 40 円で販売」がよく挙げられている。それぞれ方法が異なり, 有料化の代表的な方式と解釈さ れているようだ。図1の右には，出雲市と同様の方法をとっている自治体の「一定枚数を越えたときの袋価格」あ示 


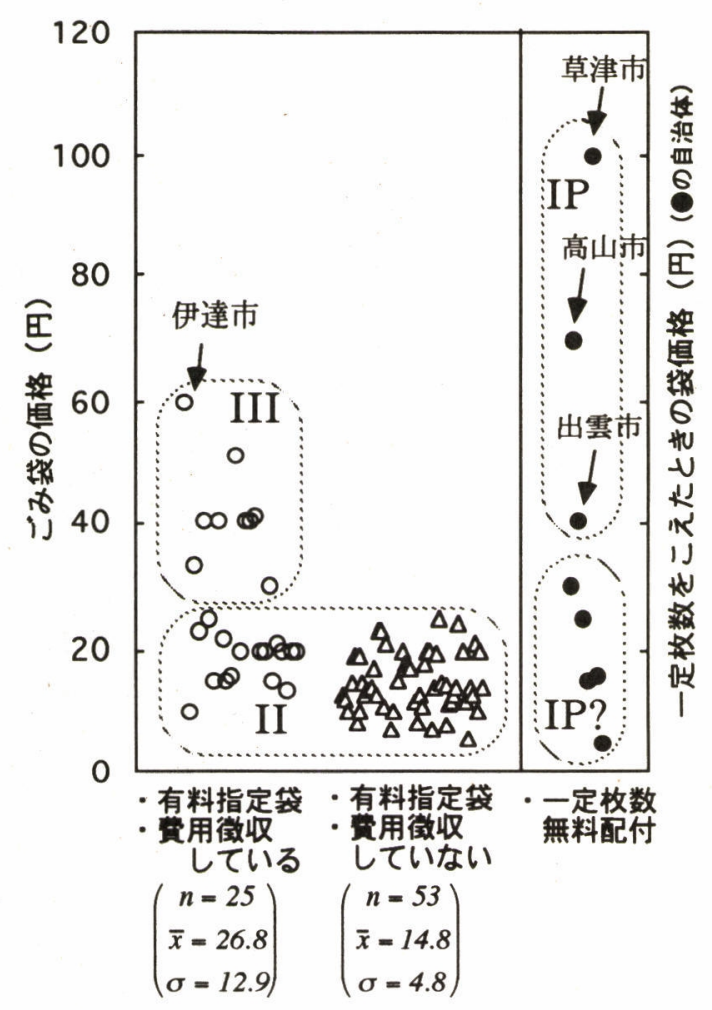

図 1 ごみ袋価格の分布 (左加北 $\rightarrow$ 南の順に亚べている)

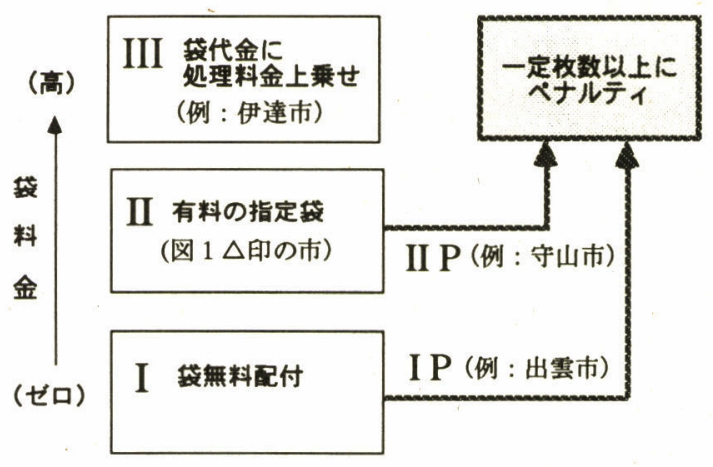

図 2 ごみ袋料金設定方式の分類

しており，いかにあ有料のように見えるが，一定枚数の 「補助」により住民は袋を買わなくてすむため, 有料化と はいいがたい。（出雲市では余った袋の買い戻しにより, さらに報奖金が得られる。）一方，守山市は途中から価格 が高くなるのが特徴だが, 出雲市も無料から有料への段階 的料金制であり, どちらあ一定量以上の排出に対するぺナ ルティ制といえる。以上のことから, 袋の基本料金（無料 配布, 袋代, 上乗せ）と, ペナルティの有無により, 袋料 金の設定方式を図 2 のように整理してみた。前述のように, 従来の方法であ住民は袋を買うのであるから袋指定ではな いが負担としてはாに属し，I（すべて無料で袋を配布）

の自治体あアンケートでは 6 市あった。また, 伊達市はIIIであり, 守山市, 出雲市はそれぞれ II, I からぺナルティ が課せられるので II P， I P と表現した。この記号を使うと図 1 の各自治体は破線のようにグループ分けでき， ○印 の市であIIに属するところもあるし，○のうち右下の自治体はペナルティ料金が低すぎて，Iに近い。

図 2 は袋価格に関する経済的手法の分類であるが，I を除くすべてをまとめて「有料化」と呼んでいるところに現 在の有料化論議における個人間あるいは自治体間の認識のずれがある。図 1 の自治体あるいは図 2 の分類のうち, ど れを有料化とするかは主観によるしかない。筆者らは何を「有料化」と呼ぶのかはそれほど重要とは考えていないが, 少なくともII と而の境界を，ごみ処理費用の適正徴収料金設定の議論により明確にすることは必要であろう。また， 現在は伊達市など，ごく限られた自治体の例をもって「有料化を行えばごみ減量効果がある」とされているが，図 2 のうちどの方法が, どのような条件, 自治体の施策を伴って有効となるのかを, 多くの事例によって検討すべきであ る。さらに, 減量効果を予測し, 効果の持続を保証するためには, なぜ, どのようにごみが減るのか（減量化された ごみはどこにいくのか）をきちんと説明することが必要である。

筆者らは, 伊達市を中心として有料化に関する研究を行っているが，ここに述べたことの確認にはかなりの時間を 要する。そこで, この欄を借りて, 広く議論を呼びかけることにした。アンダーライン部分が, 筆者らの考える論点 である。有料化に関しては, 実施に伴う経験や, さまざまな意見, 疑問をむっておられる方が多いと思う。本誌上で の「住民意識の向上」「ごみ隇量化」に対する実りある討論を期待したい。 